\title{
CONTROLLED SUCCINYLCHOLINE INFUSION IN A PATIENT RECEIVING ECHOTHIOPHATE EYE DROPS
}

\author{
F. Donati and D.R. Bevan
}

\begin{abstract}
A 69 year old man receiving echothiophate eye drops for glaucoma was given a controlled infusion of succinylcholine during elective surgery for incisional hernia. Neuromuscular blockade was assessed by the measurement of the force of contraction of the adductor pollicis muscle. Only $9.5 \mathrm{mg}$ succinylcholine were required for tracheal intubation and $1.1 \mathrm{mg} / \mathrm{min}$ for maintenance. When the infusion was stopped, recovery of neuromuscular transmission was rapid and uneventful. Plasma cholinesterase activity was 62 per cent below normal, but the enzyme was qualitatively normal. Thus, muscle relaxation can be achieved safely with a succinylcholine infusion in patients with decreased plasma cholinesterase activity if neuromuscular function is closely monitored.
\end{abstract}

Key Words: Neuromuscular Blockade, succinylcholine; Drug InTeracTION, echothiophate, succinylcholine.

EChothiophate IODIDE (phospholine iodide) eye drops, used in the treatment of glaucoma, are associated with potentiation of the action of succinylcholine. Previous reports discussed the prolonged apnoea which followed the uncontrolled administration of succinylcholine either by bolus injection $^{1}$ or continuous infusion. ${ }^{2}$

The present report demonstrates that succinylcholine can be administered safety by continuous infusion to provide controlled neuromuscular blockade sufficient for tracheal intubation and abdominal surgery if the rate of the infusion is adjusted according to the monitored muscle twitch reponse. This can be achieved without the development of dual block or prolonged apnoea when the infusion is stopped.

\section{CASE REPORT}

A 69 year old man weighing $68 \mathrm{~kg}$ was scheduled for repair of an incisional hernia. He had received general anaesthesia 17 years previously for a cholecystectomy, with thiopentone, gallamine and nitrous oxide-oxygen and halothane. No succinylcholine was given at that time.

He started using pilocarpine eye drops for

F. Donati, M.D., Ph.D., Resident; D.R. Bevan M.B., M.R.C.P., F.F.A.R.C.S., Associate Professor; Department of Anaesthesia, Royal Victoria Hospital \& McGill University, 687 Pine Avenue West, Montreal, Quebec. glaucoma 18 years ago, but they were changed to echothiophate jodide eight years ago. At the time of the present operation, he was receiving echothiophate iodide 0.125 per cent, one drop b.i.d. in both eyes. He was also using epinephrine eye drops. Otherwise, he was in good health and his pre-operative evaluation, including haemogram, routine biochemistry, chest X-ray and electrocardiogram, were within normal limits. He received morphine $10 \mathrm{mg}$ as premedication.

Anaesthesia was induced with thiopentone $350 \mathrm{mg}\left(5 \mathrm{mg} \cdot \mathrm{kg}^{-1}\right)$ and maintained with nitrous oxide (70 per cent) with oxygen and enflurane (1-2 per cent), with spontaneous respiration while the peripheral nerve stimulator and force transducer were set up. Neuromuscular transmission was monitored according to the method of Ali, et al. ${ }^{3}$ The ulnar nerve was stimulated supramaximally at the elbow using a subcutaneous needle electrode and a surface electrode. Trains of four with 0.2 millisecond square pulses at a frequency of $2 \mathrm{~Hz}$ were repeated every 10 seconds using a Grass S48 stimulator and a SIU5 Isolation Unit. The hand and forearm were immobilized in a splint and the isometric force of contraction of the adductor pollicis muscle was measured with a force-displacement transducer (Grass F.T. 10) and recorded using a pen-and-ink recorder (Grass Polygraph).

About five minutes after induction, when the recording of the train-of-four had stabilized, a succinylcholine infusion $(0.5$ per cent) was started at $6 \mathrm{mg} / \mathrm{min}\left(0.09 \mathrm{mg} \cdot \mathrm{kg}^{-1} \cdot \mathrm{min}^{-1}\right)$ and the 


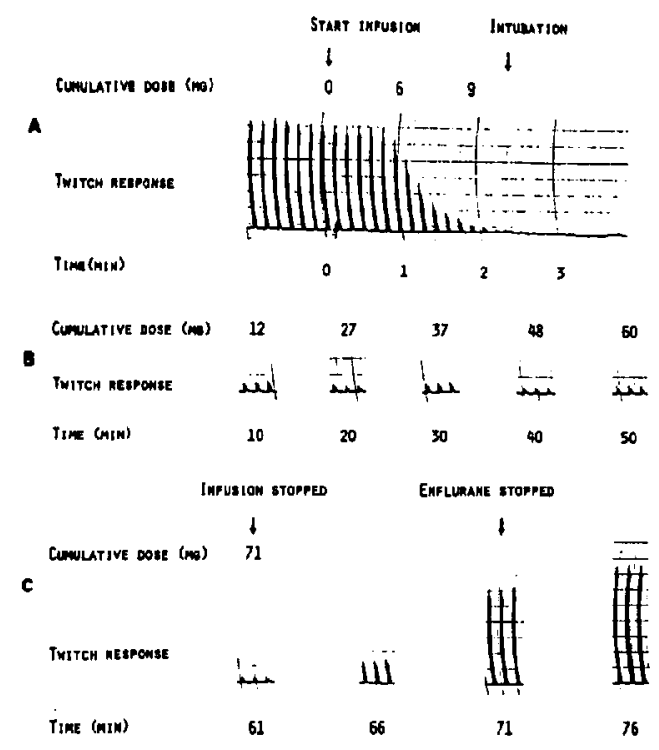

Figure 1 Train-of-four muscle twitch recording demonstrating characteristics of neuromuscular block.

twitch response was monitored (Figure la). A decrease in the twitch height was observed after 60 seconds and by 80 seconds the infusion rate was reduced to $1.5 \mathrm{mg} / \mathrm{min}$. No twitch was detectable 140 seconds after the start of the infusion. After a total succinylcholine dose of only $9.5 \mathrm{mg}$ $\left(0.14 \mathrm{mg} \cdot \mathrm{kg}^{-1}\right)$ the patient was apnoeic and the trachea was intubated under excellent conditions.

The patient was ventilated and maintenance of anaesthesia continued with nitrous oxide ( 70 per cent), oxygen and enflurane ( $1-2$ per cent). Muscle relaxation was provided by adjusting the succinylcholine infusion rate to maintain the height of the first twitch of each train at approximately 10 per cent of the initial value. After intubation, the infusion rate was slowed, then stopped, and although only $12 \mathrm{mg}$ had been given, no muscle twitch was recorded for nine minutes. Subsequent maintenance doses of succinylcholine ranged between 1.0 and $1.2 \mathrm{mg} / \mathrm{min}(0.015$ and $\left.0.018 \mathrm{mg} \cdot \mathrm{kg}^{-1} \cdot \mathrm{min}^{-1}\right)$ which provided adequate relaxation for abdominal operation (Figure lb).

The infusion was stopped after peritoneal closure, 61 minutes after it was started, after a total dose of $71 \mathrm{mg}\left(1.04 \mathrm{mg} \cdot \mathrm{kg}^{-1}\right)$ had been administered. Ten minutes later the patient began to breathe spontaneously, when the first twitch of the train-of-four was 90 per cent of its initial value and the fourth twitch was 85 per cent of the first (Figure Ic). Enflurane was turned off and five minutes later the height of the first twitch had returned to its original value, and the fourth twitch of the train was 95 per cent of the first. The trachea was extubated and recovery was uneventful. During recovery from the neuromuscular blockade, the height of the fourth twitch was 80-90 per cent of that of the first twitch, indicating a predominantly depolarizing block.

Blood was drawn the next day for plasma cholinesterase determination and showed an activity of 22.1 units $(\mathrm{N}=49-61)$; but the dibucaine, fluoride, and chloride numbers were 84,50 and 16 per cent respectively, and thus compatible with a qualitatively normal enzyme.

\section{Discussion}

Echothiophate iodide administered as an ophthalmic solution has been found to decrease plasma cholinesterase levels, ${ }^{4,5}$ and this prolongs the action of succinylcholine by slowing its metabolism. Our patient's plasma cholinesterase activity was 38 per cent of the mid-range of normal, which was similar to the mean found by Lanks and Sklar ${ }^{-4}$ (35-52 per cent) in a group of eight patients receiving echothiophate eye drops. The patients who had prolonged apnoea after normal doses of succinylcholine had a plasma cholinesterase activity of 17 per cent ${ }^{\prime}$ and 30 per cent $^{2}$ of normal. In our patient, only $9.5 \mathrm{mg}$ were required to abolish the adductor pollicis twitch reponse, and maintenance doses were only $1-1.2 \mathrm{mg} / \mathrm{min}$. In a group of 20 adult patients anaesthetized by us using the same technique, the mean intubating and maintenance doses were markedly higher, namely $45.9 \mathrm{mg}$ and $4.95 \mathrm{mg} / \mathrm{min}$ respectively.

The marked effect of succinylcholine in patients receiving echothiophate results, at least in part, from the decreased levels of plasma cholinesterase. In addition, echothiophate is an inhibitor of acetylcholinesterase, which is the reason for its use in ophthalmology. Thus, it potentiates the action of succinylcholine like other anticholinesterases such as neostigmine and edrophonium, and this may explain why only 20 per cent of the normal infusion dose of succinylcholine was required to maintain neuromuscular blockade in a patient whose plasma cholinesterase activity was 38 per cent of normal.

Thus plasma cholinesterase levels are probably not the only predictors of the required dose of succinylcholine, and adequate monitoring of the neuromuscular junction is therefore essential. In our patient plasma cholinesterase levels were not 
available at operation, but continuous neuromuscular monitoring was sufficient to avoid the problem of prolonged apnoea. ${ }^{1.2}$ The transducer and recording equipment were used for convenience and to obtain a permanent record, but the same results could probably have been achieved with a conventional $2 \mathrm{~Hz}$ nerve stimulator.

The prior administration of echothiophate eye drops is one of a large number of congenital and acquired conditions which may affect the plasma cholinesterase in a qualitative or quantitative manner. ${ }^{6}$ Many of these are not uncommon, including contraceptive pills, pregnancy, organophosphorous insecticides. This case report suggests that careful monitoring of the neuromuscular junction allows succinylcholine to be used safely in these conditions without the risk of prolonged apnoea.

\section{REFERENCES}

1. Gesztes, T. Prolonged apnoea after suxamethonium injection associated with eye drops containing an anticholinesterase agent. Brit. J. Anaesth. 38: 408 (1966).

2. PAntuck, E.J. Echothiophate iodide eye drops and prolonged response to suxamethonium. Brit. J. Anaesth. 38: 406 (1966).

3. Ali, H.H., Utring, J.E. \& GRaY, T.C. Quantitative assessment of residual antidepolarising block (Part I). Brit. J. Anaesth. 43: 473 (1971).

4. Lanks, K.W. \& SkLaR, G.S. Pseudocholinesterase levels and rates of chloroprocaine hydrolysis in patients receiving adequate dose of phospholine iodide. Anesthesiology 52: 434 (1980).

5. McGavi, D.D.M. Depressed levels of serum pseudocholinesterase with echothiophate iodide eye drops. Lancet $i: 272$ (1965).

6. Whittaker, M. Plasma cholinesterase variants and the anaesthetist. Anaesthesia 35: 174 (1980).

\section{RÉSUMÉ}

Un homme de 69 ans souffrant de glaucome traité avec des gouttes d'échothiophate a reçu une perfusion controlée de succinylcholine pendant une cure de hernie incisionnelle en chirurgie réglée. Le bloc neuro-musculaire a été évalué par la mesure de la force de contraction de l'adducteur du pouce. Seulement $9.5 \mathrm{mg}$ de succinylcholine ont été nécessaires pour l'intubation et $1.1 \mathrm{mg}$ à la minute pour le maintien de la relaxation. Après l'arrêt de la perfusion, la récupération de la transmission neuro-musculaire s'est faite repidement et sans histoire. L'activité de la cholinestérase plasmatique était de 62 pour cent sous la normale, mais ne présentait pas d'anomalie qualitative. Une relaxation musculaire satisfaisante peut donc être obtenue en toute sécurité avec une infusion de succinylcholine chez des malades dont l'activité de la plasma cholinestérase est diminuée si on prend bien soin de monitorer la fonction nuro-musculaire. 